\title{
Penentuan Derajat Toksisitas Akut Ekstrak Air Buah Pepaya (Carica papaya L.) Muda Pada Mencit Menggunakan Purposed New Recommended Method
}

\author{
Penulis \\ Laila Dinda Nadiyah ${ }^{*}$, Yuktiana Kharisma, Yuniarti \\ Afiliasi \\ Fakultas Kedokteran, Universitas Islam Bandung, Indonesia
}

Kata Kunci
$\Rightarrow$ Unripe Carica papaya
L. fruit aqueous
extract
$\Rightarrow$ degree of acute
toxicity
$\Rightarrow \mathrm{LD}_{50}$

Diterima 7 September 2015 Direvisi 7 Desember 2015 Disetujui 4 Maret 2016

*Penulis korespondensi Laila Dinda Nadiyah Fakultas kedokteran Universitas Islam Bandung, Jalan Hariangbanga No.2 Tamansari-Bandung, West Java, Indonesia

laila.dinda.nadiyah.xi.si.1@gmail .com

\begin{abstract}
Abstrak
Papaya (Carica papaya L.) fruit was proven scientifically in having medicinal effects: such as gastroprotective, laxative, galactagogues, and antibacterial effect. Unripe papaya fruit contains saponin, alkaloid, tannin, flavonoid, triterpenoid, and quinone which may reveal toxicities as adverse effect when it consumed in high dose. The aim of this study is to determine the acute toxicity degree of unripe Carica papaya L. fruit aqueous extract in mice using proposed new recommended method. The acute toxicity degree conducted by determination of lethal dose ${ }_{50}\left(L_{50}\right)$ using new recommended method to 12 female mice. The subjects were divided into three stages and each mouse was given different dose of the extract. $L_{50}$ calculated by mean of mortality lowest dose and non mortality highest dose then the result classified into the degree of acute toxicity. The study showed there was no mortality in all groups of the experimental subject. $\mathrm{LD}_{50}$ of unripe Carica papaya $\mathrm{L}$. aqueous extract was found $>5000$ $\mathrm{mg} / \mathrm{kg} \mathrm{BW}$ and classified as Practically Non Toxic (PNT) substance.
\end{abstract}

\section{Pendahuluan}

Obat tradisional Indonesia merupakan warisan budaya yang perlu dilestarikan, diteliti, dan dikembangkan. Penelitian di bidang tanaman obat penting untuk dilakukan guna memanfaatkan tanaman tersebut sebagai bahan pengobatan bagi manusia. Penelitian obat tradisional yang berasal dari bahan alam umumnya berupa jenis penelitian budidaya tanaman obat, analisis kandungan kimia, toksisitas, farmakodinamik, formulasi dan uji klinik (Dewoto 2007).

Salah satu jenis bahan alam yang secara umum dimanfaatkan oleh masyarakat adalah buah pepaya. Efek gastroprotektif, laksatif, laktagogum, dan antibakterial merupakan khasiat yang terbukti secara ilmiah dari buah pepaya (Aravind et al. 2013; Kharisma et al. 2011). Pepaya mengandung substansi beberapa fitokimia seperti saponin, alkaloid, tanin, flavonoid, triterpenoid, dan kuinon (Iwuagwu et al. 2013). Konsumsi buah pepaya dengan kandungan substansi fitokimia dalam jumlah tinggi diketahui dapat menimbulkan efek samping bagi tubuh berupa efek toksik, sehingga uji toksisitas akut sebagai salah satu jenis uji preklinik perlu dilakukan untuk mengetahui 
tingkat keamanan tanaman obat tradisional (Dewoto 2007; Iwuagwu et al. 2013)

Pada uji toksisitas akut kali ini digunakan buah pepaya muda yang memiliki kandungan nutrisi yang lebih tinggi dibandingkan buah yang sudah matang, berupa kandungan karbohidrat, lemak, protein, serat, vitamin C, mineral (kalsium, kalium, fosforus, magnesium), dan enzim (papain, chymopapain) (Iwuagwu et al. 2013). Pengamatan terhadap mortalitas hewan uji dilakukan selama 24 jam. Data yang diperoleh digunakan sebagai data awal evaluasi karakteristik toksik substansi fitofarmaka (BPOM 2014). Metode kuantitatif berupa penentuan lethal dose 50 $\left(\mathrm{LD}_{50}\right)$ merupakan metode tersering yang digunakan dalam penilaian uji toksisitas akut (Paramveer et al. 2010). Hasil $\mathrm{LD}_{50}$ dapat menentukan kriteria penggolangan derajat toksisitas substansi fitofarmaka yang diklasifikasikan menjadi luar biasa toksik, sangat toksik, toksik sedang, toksik ringan, praktis tidak toksik, dan relatif tidak membahayakan (BPOM 2014).

Penelitian terbaru oleh Chinendu dkk menyebutkan metode proposed new recommended disarankan untuk digunakan dalam menentukan $\mathrm{LD}_{50}$ suatu substansi fitofarmaka karena memiliki beberapa keunggulan dibanding metode sebelumnya berupa hasil akhir yang didapatkan lebih akurat, penggunaan jumlah hewan uji yang minimal, proses uji toksisitas yang relatif lebih sederhana dengan durasi penelitian yang lebih singkat (Chinedu et al. 2013). Penelitian tentang toksisitas akut ekstrak air buah pepaya muda pada tahun 2007 yang dilakukan oleh Oduola et al. (2007) menggunakan metode Karber menunjukan hasil $\mathrm{LD}_{50}$ sebesar $2520 \mathrm{mg} / \mathrm{kgBB}$. Sementara itu, toksisitas akut ekstak air buah papaya muda dengan menggunakan metode proposed new recommended pada penelitian ini didapatkan $L_{50}$ sebesar $>5000$ $\mathrm{mg} / \mathrm{kgBB}$. Kedua hasil tersebut menunjukan toksisitas ekstrak air buah papaya muda yang sangat ringan. Hingga saat ini di Indonesia belum ada laporan mengenai efek toksisitas ataupun efek samping yang membahayakan dari mengonsumsi buah pepaya. Oleh karena itu, tujuan dari penelitian ini adalah untuk menentukan derajat toksisitas akut ekstrak air buah pepaya muda pada mencit menggunakan metode proposed new recommended.

\section{Metode Penelitian}

Bahan penelitian berupa buah pepaya muda varietas Paris yang tidak dikupas (termasuk biji) dengan umur buah sekitar 2.5-3 bulan, buah keras padat, kulit buah berwarna hijau, dan biji berwarna putih. Buah pepaya berasal dari perkebunan pepaya di Kecamatan Leles, Kabupaten Garut, Jawa Barat. Dua belas ekor mencit betina (Mus musculus) galur Swiss Webster usia 6-8 minggu dengan berat badan 25-30 gram dibagi ke dalam tiga tahap uji toksisitas yaitu uji toksisitas tahap satu menggunakan dosis tunggal pada konsentrasi rendah, uji toksisitas tahap dua menggunkan dosis tunggal pada konsentrasi sedang, dan uji toksisitas tahap tiga menggunakan dosis tunggal pada konsentrasi tinggi serta satu tahap uji konfirmasi digunakan sebagai subjek penelitian.

Penelitian eksperimental laboratorium ini dilaksanakan di Laboratorium Biologi Medik Fakultas Kedokteran Universitas Islam Bandung (UNISBA). Metode proposed new recommended dipilih untuk digunakan dalam penelitian uji toksisitas ini. Dosis tunggal pada tahap pertama sebesar $50,200,400,800$ $\mathrm{mg} / \mathrm{kg} \mathrm{BB}$; tahap kedua sebesar 1000, 1500, 2000 $\mathrm{mg} / \mathrm{kg} \mathrm{BB}$; dan tahap ketiga sebesar 3000, 4000, 5000 $\mathrm{mg} / \mathrm{kgBB}$ (berat badan) masing-masing diberikan secara peroral. ${ }^{7}$ Pada tahap pertama, mencit diamati tingkah lakunya selama 1 jam setelah diberi sampel kemudian diamati selama 10 menit tiap dua jam selama 24 jam. Tingkah laku yang menunjukan toksisitas dan mortalitas dicatat. Jika pada tahap pertama tidak didapatkan mencit yang mati maka dilanjutkan ke tahap kedua. Pada tahap kedua pengamatan yang dilakukan sama dengan tahap pertama. Jika pada tahap kedua tidak didapatkan mencit yang mati maka dilanjutkan ke tahap ketiga dan pengamatan yang dilakukan sama dengan tahap pertama dan kedua. Jika tidak didapatkan mencit yang mati maka dosis tertinggi pada uji toksisitas tahap ketiga digunakan sebagai dosis toksisitas sampel yang akan divalidasi melalui uji konfirmasi. Uji Konfirmasi dilakukan menggunakan dosis terendah yang tidak menimbulkan kematian. Apabila pada uji konfirmasi dengan dosis tertinggi sampel yaitu sebesar $5000 \mathrm{mg} / \mathrm{kgBB}$ tidak didapatkan mencit yang mati maka $L_{50}$ dinyatakan sebesar $>5000$ $\mathrm{mg} / \mathrm{kgBB}$. Pada penelitian ini dosis uji yang digunakan mulai dari dosis terendah hingga tertinggi yang bertujuan untuk melihat batasan toksisitas mulai dari dosis terendah. 
Hasil $L_{50}$ dihitung melalui rumus yang telah ditentukan oleh metode proposed new recommended berupa hasil rata-rata penjumlahan dosis tertinggi ekstrak yang tidak menimbulkan kematian dan dosis terendah ekstrak yang menimbulkan kematian. Pada analisis akhir, nilai $\mathrm{LD}_{50}$ yang didapat menentukan ekstrak air buah pepaya muda tersebut diklasifikasikan pada derajat toksisitas akut tertentu dari suatu substansi fitofarmaka.

$$
\mathrm{LD}_{50}=\frac{\left(\mathrm{M}_{0}+\mathrm{M}_{1}\right)}{2}
$$

Keterangan :

$\mathrm{M}_{0}$ = dosis tertinggi dari ekstrak air buah pepaya muda yang tidak menimbulkan kematian.

$\mathrm{M}_{1}=$ dosis terendah dari ekstrak air buah pepaya muda yang menimbulkan kematian.

Hasil

Pada penelitian ini diperoleh hasil berupa tidak ada hewan uji yang mati ataupun tingkah laku mencit yang menunjukkan gejala toksisitas seperti piloereksi, grooming, straub, tremor, kejang, peningkatan righting reflex, dan eksoptalamus pada keseluruhan tahap uji toksisitas setelah 24 jam pemberian dosis tunggal ekstrak air buah pepaya muda (dosis 50 s.d. 5000 $\mathrm{mg} / \mathrm{kg}$ BB). Pada uji konfirmasi hasil yang sama diperoleh berupa tidak ada hewan uji yang mati dan menunjukan gejala toksisitas setelah pemberian dosis tertinggi ekstrak strsebesar $5000 \mathrm{mg} / \mathrm{kg}$ BB. $\quad$ LD $_{50}$ ekstrak air buah pepaya muda didapatkan sebesar $>5000 \mathrm{mg} / \mathrm{kg}$ BB dan diklasifikasikan ke dalam kriteria derajat toksisitas akut sebagai substansi yang Praktis Tidak Toksik (PTT).

\section{Pembahasan}

Berdasarkan hasil penelitian, toksisitas akut ekstrak air buah pepaya muda menggunakan metode proposed new recommended didapatkan nilai $\mathrm{LD}_{50}$ sebesar $>5000 \mathrm{mg} / \mathrm{kg}$ BB. Hodge dan Sterner

Tabel 1. Toksisitas Hewan Coba Pada Beberapa Dosis Dalam Uji Tahap I, II, III, dan Uji Konfirmasi

\begin{tabular}{lccl}
\hline $\begin{array}{c}\text { Tahapan } \\
\text { Uji }\end{array}$ & $\begin{array}{c}\text { Dosis* } \\
\text { (mg/kgBB per oral) }\end{array}$ & (Mati/Hidup) & \multicolumn{1}{c}{ (Gejala Toksisitas) } \\
\cline { 2 - 4 } & 50 & Hidup & Tidak ada gejala piloereksi, grooming, \\
Uji Tahap I & 200 & Hidup & $\begin{array}{l}\text { straub, tremor, kejang, righting reflex, } \\
\text { eksopthalamus. }\end{array}$ \\
& 400 & Hidup & \\
\hline Uji Tahap II & 800 & Hidup & \\
& 1000 & Hidup & Tidak ada gejala piloereksi, grooming, \\
& 1500 & Hidup & straub, tremor, kejang, righting reflex, \\
& 2000 & Hidup & Tidak ada gejala piloereksi, grooming, \\
Uji Tahap III & 3000 & Hidup & straub, tremor, kejang, righting reflex, \\
& 4000 & Hidup & eksopthalamus. \\
\hline Uji Konfirmasi & 5000 & Hidup & Tidak ada gejala piloereksi, grooming, \\
& 5000 & Hidup & straub, tremor, kejang, righting reflex, \\
& 5000 & & eksopthalamus. \\
\hline
\end{tabular}

Keterangan: *Dosis ditentukan berdasarkan proposed (new) recommended method (Chinedu et al. 2013).

Tabel 2. Kriteria Penggolongan Derajat Toksisitas Sediaan Uji Berdasarkan Hodge dan Sterner

\begin{tabular}{cll}
\hline Tingkat Toksisitas & \multicolumn{1}{c}{ LD50 oral } & \multicolumn{1}{c}{ Klasifikasi } \\
\hline 1 & $<1 \mathrm{mg} / \mathrm{kgBB}$ & Luar biasa toksik \\
2 & $1-50 \mathrm{mg} / \mathrm{kgBB}$ & Sangat toksik \\
3 & $50-500 \mathrm{mg} / \mathrm{kgBB}$ & Toksik sedang \\
4 & $500-5000 \mathrm{mg} / \mathrm{kgBB}$ & Toksik ringan \\
5 & $5-15 \mathrm{~g} / \mathrm{kgBB}$ & Praktis tidak toksik \\
6 & $>15 \mathrm{~g} / \mathrm{kgBB}$ & Relatif tidak membahayakan \\
\hline
\end{tabular}

Dikutip dari : Peraturan Kepala Badan Pengawasan Makanan RI No. 7 Tahun 2014 
mengklasifikasi nilai $\mathbf{L D}_{50}$ ke dalam substansi yang derajat toksisitas akutnya bersifat Praktis Tidak Toksik (PTT). ${ }^{5}$ Saponin, alkaloid, tanin, flavonoid, triterpenoid, dan kuinon dikonfirmasi sebagai substansi fitokimia pada ekstrak air buah pepaya muda setelah dilakukan skrining fitokimia dengan metode kualitatif.

Kandungan suatu substansi (toksin atau racun) berpotensi menimbulkan gejala toksisitas bagi tubuh manusia tergantung pada kuantitas zat metabolit tersebut pada obat tradisional. Penelitian mengenai toksisitas fitofarmaka penting dilakukan guna mengetahui efek samping yang bersifat fatal dan membahayakan (Hodgson 2004). Pada penelitian ini dimungkinkan kandungan substansi fitokimia tersebut berkontribusi terhadap efek toksisitas yang minimal dari ekstrak air buah pepaya muda. Efek yang minimal dapat terjadi akibat interaksi yang terjadi antar substansi fitokimia yang dapat bersifat saling menguatkan atau dikenal dengan efek positif ataupun efek yang saling melemahkan bahkan meniadakan aktivitas biologis substansi fitokimia satu sama lain atau yang dikenal dengan efek negative (Lila \& Raskin 2005).

Faktor lain yang kemungkinan berpengaruh terhadap keberagaman kandungan substansi fitokimia yang dalam hal ini berperan sebagai zat yang mampu menimbulkan efek yang positif dan negatif pada tanaman obat adalah faktor eksternal dan internal dari tumbuhan obat tersebut. Faktor internal meliputi faktor genetik dan varietas tanaman sementara faktor eksternal berupa perbedaan letak geografis dan kondisi lingkungan. Pada penelitian ini digunakan pepaya varietas Paris yang memiliki keunggulan berupa kandungan lateks yang lebih tinggi dibanding dengan varietas lain (Figueiredo et al. 2008).

Pada penelitian ini, penilaian faktor yang mempengaruhi variasi kandungan fitokimia pada tanaman obat kemungkinan diarahkan lebih terhadap faktor eksternal berupa perbedaan letak geografis yang saling terkait dalam mempengaruhi kondisi lingkungan tempat tanaman obat tersebut tumbuh dan berkembang. Buah pepaya yang digunakan dalam penelitian ini berasal dari perkebunan pepaya di Leles, Kabupaten Garut. Suhu, kelembapan, intensitas cahaya, kandungan mineral, suplai air, dan karbondioksida diketahui sebagai komponen dari kondisi lingkungan yang mempengaruhi perkembangan tanaman obat (Ramakrishna \& Ravishankar 2011).

Keberagaman substansi fitokimia, interaksinya dalam menimbulkan efek dari suatu tanaman obat, serta faktor eksternal maupun internal berpengaruh terhadap efek toksisitas yang timbul. Pada penelitian ini, dimungkinkan varietas buah pepaya yaitu varietas Paris, letak geografi serta kondisi lingkungan mempengaruhi kandungan substansi fitokimia dan interaksi yang terjadi diantara substansi tersebut. Interaksi yang terjadi antar substansi fitokimia pada ekstrak air buah pepaya muda ini kemungkinan belum cukup secara kuantitas maupun kualitas sehingga belum memadai untuk menimbulkan efek kematian pada hewan uji dan memberikan hasil akhir berupa derajat toksisitas akut yang tergolong Praktis Tidak Toksik (PTT).

\section{Simpulan}

Ekstrak air buah pepaya muda memiliki $\mathrm{LD}_{50}$ pada mencit sebesar $>5000 \mathrm{mg} / \mathrm{kg}$ BB menggunakan

Tabel 3. Kandungan Fitokimia Ekstrak Air Buah Pepaya (Carica papaya L.) Muda Secara Kualitatif

\begin{tabular}{|c|c|c|c|c|}
\hline No. & Golongan Senyawa & Reaksi & Hasil Uji* & Keterangan \\
\hline 1 & Alkaloid & $\begin{array}{l}\text { Sampel + Dragendroff }+\mathrm{CHCl}_{3}+ \\
\mathrm{HCl}\end{array}$ & $(+)$ & Terbentuk warna jingga \\
\hline 2 & Flavonoid & Sampel $+\mathrm{Mg}+\mathrm{HCl}+$ Amil Alkohol & $(+)$ & Terbentuk warna merah bata \\
\hline 3 & Saponin & Sampel + $\mathrm{HCl}$ (dikocok) & $(+)$ & Terbentuk busa \\
\hline 4 & Tannin & $\begin{array}{l}\text { Sampel + pereaksi Steasny* } \\
\text { (dipanaskan) }\end{array}$ & $(+)$ & Terbentuk endapan merah \\
\hline 5 & Quinon & Sampel $+\mathrm{NaOH}$ & $(+)$ & Terbentuk warna coklat pekat \\
\hline 6 & $\begin{array}{l}\text { Steroid/ } \\
\text { Triterpenoid }\end{array}$ & $\begin{array}{l}\text { Sampel }+ \text { Eter }+\mathrm{H}_{2} \mathrm{SO}_{4}+\mathrm{Asam} \\
\text { asetat glasial }\end{array}$ & $(+)$ & Terbentuk warna merah, ungu, hitam \\
\hline
\end{tabular}

*Keterangan:

(+) = ada kandungan senyawa fitokimia pada ekstrak

Perekasi Steasny = campuran formaldehida $30 \%$ dan asam klorida pekat $(\mathrm{HCl})$ dengan perbandingan 2:1 
metode proposed new recommended dan dengan derajat toksisitas akut Praktis Tidak Toksik (PTT). Pemberian ekstrak air buah pepaya muda hingga dosis uji tertinggi tidak menimbulkan gejala toksisitas pada mencit. Saran pada penelitian ini adalah perlunya dilakukan uji toksisitas terhadap efek sistemik seperti pemeriksaan histopatologi organ, pemeriksaan biokimia berupa kadar enzim dan metabolit yang menunjukan kerusakan organ, serta pemeriksaan komponen hematologi.

\section{Ucapan Terima kasih}

Terimakasih kepada pihak Laboratorium Biomedik Fakultas Kedokteran Universitas Islam Bandung (UNISBA) atas segala fasilitas yang diberikan selama penelitian ini, serta staff laboratorium atas bantuan teknis yang diberikan sehingga peneltian ini dapat terlaksana dengan lancar.

\section{Daftar Pustaka}

Aravind G, Bhowmik D, Duraivel S, Harish G. 2013. Traditional and medicinal uses of Carica papaya. Journal of Medicinal Plants Studies. 1(1):7-15.

BPOM. 2014. Pedoman uji toksisitas nonklinik secara in vivo. Peraturan Kepala Badan Pengawas Obat dan Makanan Republik Indonesia No. 7 Tahun 2014.

Chinedu E, Arome D, Ameh FS. 2013. New recomended method for determining acute toxicity in animal models. Toxicology International.. 20(3):224-6.

Dewoto HR. 2007. Pengembangan obat tradisional Indonesia menjadi fitofarmaka. Maj Kedokt Indon. 57(7):205-11.
Figueiredo AC, Barroso JG, Pedro LG, Scheffer JJC. 2008. Factors affecting secondary metabolite production in plants: volatile components and essential oils. Flavour and Fragrance Journal. 23(4):213-26.

Kharisma Y, Ariyoga A, Sastramihardja HS. 2011. Efek ekstrak air buah pepaya (Carica papaya L.) muda terhadap gambaran histologi kelenjar mamma mencit laktasi. MKB.43(4):160-5.

Hodgson E. 2004. Introduction to toxicology. In: Hodgson $\mathrm{E}$, penyunting. A textbook of modern toxicology. Edisi ke-3. New Jersey (AS):Wiley \& Sons, Inc.

Iwuagwu M, Chukwuka KS, Uka UN. 2013. Evaluation of nutritional components of Carica papaya L. at different stages of ripening. Journal of Pharmaceutical and Biological Sciences. 6(4):13-6.

Lila MA, Raskin I. 2005. Health-related interactions of phytochemical. Journal of Food Science. 70(1):21-7.

Paramveer D, Chancal M, Paresh M, Rani A, Nema RK. 2010. Effective alternative methods of LD50 help to save number of experimental animals. Journal of Chemical and Pharmaceutical Research. 2(6):450-3.

Oduola T, Adeniyi FAA, Ogunyemi EO, Bello IS, Idowu TO, Subair, HG. 2007. Toxicity studies on an unripe Carica papaya aqueous extract: biochemical and haematological effects in wistar albino rats. Journal of Medicinal Plants Research. 1(1):1-4.

Ramakrishna A, Ravishankar GA. 2011. Influence of abiotic stress signals on secondary metabolites in plants. Plant Signaling and Behavior Landes Bioscience. 6(11):1720-31. 